\title{
外傷性両側外耳道閉鎖症例
}

\author{
大石 公子・伊藤 博・間島 雄一 \\ 坂倉 康夫・三吉 康郎
}

\section{Post-Traumatic Bilateral Atresia of the External Auditory Canals}

\author{
Kimiko Ohishi, Hiroshi Ito, Yuichi Majima, \\ Yasuo Sakakura and Yasuro Miyoshi
}

(Mie University)

\begin{abstract}
A patient developed atresia of both external auditory canals following a traffic accident. Bilateral atresia of the auditory canals is very rare and has never been reported in Japan. The occluded portions of the canals were resected through a postauricular approach. In the right external auditory canal, a cholesteatoma-like accumulation was found behind the obstruction. The operation restored the hearing in both ears to nearly normal. Twenty-two cases of post-traumatic atresia of an external auditory canal reported to date in Japan are reviewed, and the pathology, pathogenesis and treatment are discussed.
\end{abstract}

Key words : acquired atresia, external auditory canal, post-traumatic

後天性外耳道閉鎖症は, 比較的稀な疾患で外傷, 火傷, 感染症, 手術などによって生ずる瘢痕に 基づくことが多いとされている，我々は，最近，下顎骨骨折に合併した両側性の外傷性外耳道閉鎖 症の 1 症例を経験したので若干の考察を加え報告する.

症

患者:

56才，男子.

初診：昭和58年 4 月 4 日

初診時主訴 : 両側難聴, 開口障害.

既往歴および家族歴：特記すべきことなし.

現病歷: 昭和 58 年 2 月 16 日, 単車走行中, 谷 へ転落, 風防ガラスで下顎部を突き上げるよう に強打して下顎正中部骨折をきたした，受傷 時, 両耳内よりの出血が認められた。受傷後 14 日目に，某市民病院口腔外科で，下顎骨正中部 観血的整復固定術を受けたが，その後も開口障
例

害, 両側難聴を訴え, 両側外耳道の閉鎖が認め られたため，受傷後 48 日目に当科外来を受診し た.

現症：左煩部やや腫脹し，開口は $20 \mathrm{~mm}$ 程度に 制限されていた. 左外耳道は, 入口部より $1 \mathrm{~cm}$ の深さで完全閉鎖し，右外耳道も入口部より 1 $\mathrm{cm}$ の深さで閉鎖し, 深部之針穴程度の交通を残 すのみで, 漿液性分泌物を認めた。

聴力検查: 聴力損失は 4 分法にて右 $51 \mathrm{~dB}$, 左38dBで，伝音性難聴を示した（図1）. 


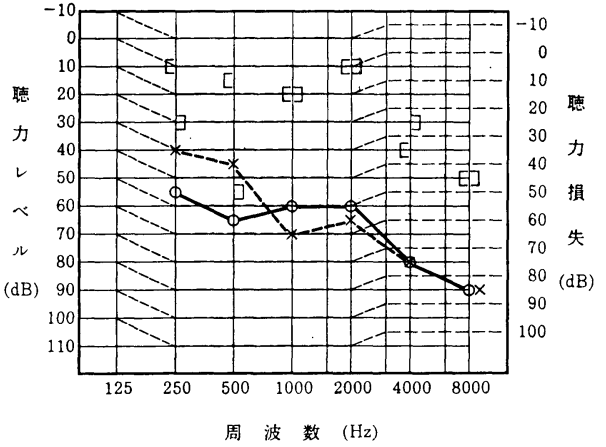

図 I 初喨時聴力像

レ線所見：中耳, 乳様蜂巣および内耳に異常 を認めず，側頭骨に骨折像は認めなかった。下 顎正中部骨折線, 両側の下顎骨関節突起骨折お よびその後上方への移動, 左側筋突起の骨折を 認めた。

C T 所見：両側外耳道は軟部組織によりほぼ 閉塞していた.

開口障害（開口 $20 \mathrm{~mm}$ ）による顎関節部矯正の ため, 口腔外科に入院し, デンチャ一を装着し ての開口練習を行ない開口 $42 \mathrm{~mm}$ まで可能となっ たが，難聴は軽快せず受傷後76日目に手術目的 で当科に転科した。転科時の局所所見, 聴力. レ線像は, 初診時と変化なかった。

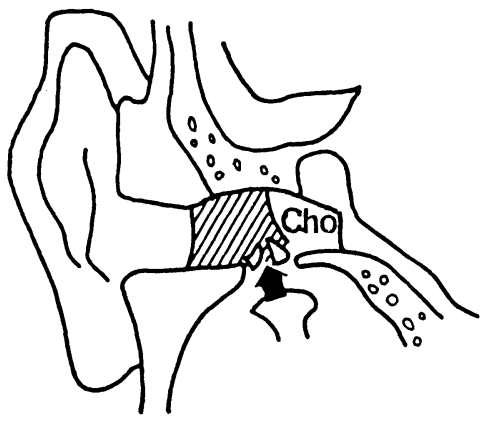

手術所見および経過：受傷後98日目に modified NLA下に左外耳道形成術, 植皮術を施行 した.耳後切開で外耳道を開放すると，外耳道 孔より $1 \mathrm{~cm}$ の深さから, 骨部外耳道入口部付近 まで痏痕性肉芽組織により閉鎖しており，てれ より深部は開存し鼓膜は正常であった（図 2 ,

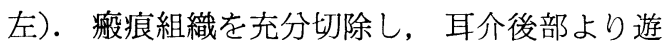
離植皮片を採取, 外耳道前壁の皮虐欠損部にあ て外耳道皮膚と 2,3 針縫合し, 圧迫タンポン を插入した，次いで，受傷後 123 日目に，右外 耳道形成術を施行した．耳後切開で外耳道を開 放した．外耳道孔より $1 \mathrm{~cm}$ 深さから骨部外耳

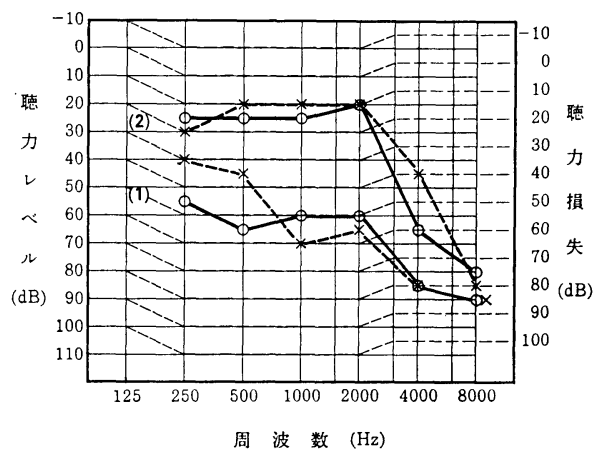

図 3 手術前後の聴力像の比較

(1)術前（2)術後

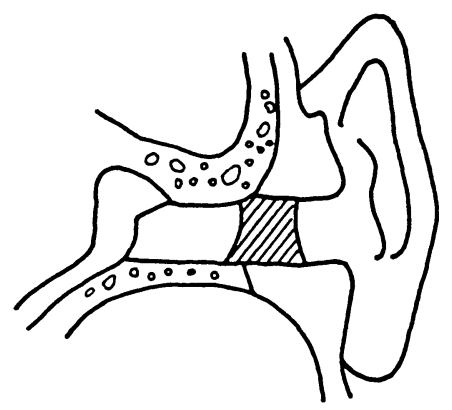

図2 右は左側外耳道開鎖状態を，左は右側外耳道閉鎖状態を示す. 右側外耳道では，矢段の方向につきあげられた顎関節突起 により前下壁骨折をきたしたものと推測される。

斜線部分：閉塞部位

cho：真珠腫様物質 
道前下壁の骨が骨片として外耳道内に遊離し, これを中心に肉芽が増殖し，肉芽と鼓膜の間に 真珠腫樣物質を認めた。鼓膜は正常であった

(図 2 , 右). 肉芽を充分除去し骨部外耳道後 壁を削開拡大した。外耳道皮膚欠損部に植皮は 行なわず圧迫タンポンを挿入した。圧迫タンポ ンは, 両側とも術後 7 日目に抜去した. 左外耳 道の皮膚遊離植皮弁は脱落したが，両外耳道は

\section{考}

外傷性外耳道閉鎖症の報告例は, 我国では関

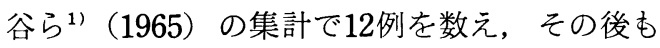
後藤ら以下数例が報告されている（表 1 ）。 ま た外国では, Conley ${ }^{17)}$ の銃弾によって生じた 10例の発表をはじめとし, 最近では, Miller ${ }^{18)}$

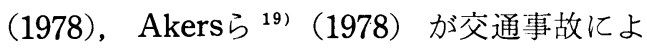
り生じた外耳道閉鎖症症例を報告している，自 験例は単車走行中, 転倒し風防ガラスで下顎部 を下方から突き上げる外力をうけ，両側外耳道 閉鎖となった症例であるが，過去の報告例は全 て一側のみの病変であり自験例のような両側性 のものは報告をみない，以下，過去の報告例を 屯とに, 原因, 症状, 治療等について考察を加 えた。

\section{1. 原因之成因}

本症は, 外耳道の挫創, 切創, 銃創, 骨折な どが原因となっている. 松崎ら ${ }^{13)}$ は, 物理化学 的損傷, 火傷, 熱傷, X線照射もこの範疇に加 えている. これらの原因のいずれかによって外 耳道皮膚の損傷がおこり，修復機転として肉芽 が新生し，適切な治療が行なわれないと 2 次感 染が加わり過剩肉芽が発生, これが線維化, 洀 痕化し外耳道狭窄閉鎖が成立する。自験例に於 ける外耳道閉鎖機転について考察してみる.才 トガイ部打撲により，下顎の前部から後上方へ の力が加わり，つきあげられた顎関節突起によ り右外耳道では前下壁骨折をきたした．左外耳 道については, 明確な骨折線は認められなかっ たが, 骨部外耳道の一部に小さい亀裂が生じ, 小さな骨片が遊離しこれを中心に肉芽が増生し
広く開放され，狭窄はみられなかった。術後約 1 力月目に, 右外耳道上壁より肉芽の増殖を認 めたため外来にて鉗除した。術後約 20 力月の現 在, 両側外耳道はほぼ正常に開存している. 術 後の聴力損失は 4 分法にて, 右 $14 \mathrm{~dB}$, 左 $10 \mathrm{~dB}$ で術前に比し, 右 $37 \mathrm{~dB}$, 左 $28 \mathrm{~dB}$ の聴力の改善 をみた（図 3 ).

\section{察}

たあのと思われる. あるいは図 4 に示す如く, 下顎骨関節突起の後部外側は, 骨, 軟骨が存在 せず軟部組織で被われているだけなので, ての 抵抗の弱い部分が損傷され, 肉芽が増生閉塞し たとも考えられる。

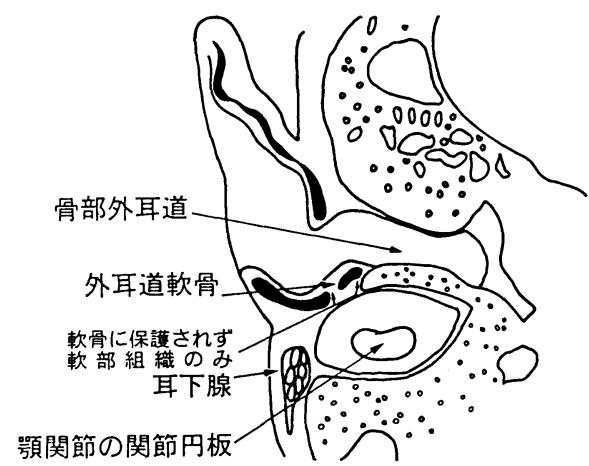

図 4 外耳道前頭断図

顎関節突起の後部外側は, 軟骨に保護され ず軟部組織のみのため，抵抗が弱く損傷さ れやすい.

\section{2. 頻度}

報告例数のみから，その頻度を推定すること は困難であるが, 近年交通事故の激増に伴い本 症例が増加傾向にあるととは, まちがいないと 思われる. 報告症例をみると（表 1 ), 最近, 交通事故による頭蓋骨骨折に起因する骨部外耳 道閉鎖（症例番号15,18），耳介後部の切創， 裂創に起因する軟骨部あるいは入口部閉鎖（症 例番号16，17，20，21）が多い様である。

3 . 症状 


\begin{tabular}{|c|c|c|c|c|c|c|c|c|c|c|c|c|}
\hline 報告者 & 報告年. & 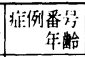 & 受偤原闪 & \begin{tabular}{|l|} 
受傷後耳出血 \\
取処置状況 \\
\end{tabular} & \begin{tabular}{|l|}
$\begin{array}{l}\text { 初䜪時ま } \\
\text { でのH数 }\end{array}$ \\
\end{tabular} & 占覚聇状 & 㖣断機会 & 閉銷部位. & 乎術所見 & 治 & \begin{tabular}{|l|} 
聴力 \\
気導/出毞 \\
\end{tabular} & 閉 鎖 状 態 \\
\hline 吉井2) & 1904 & 1 & 位柇故 & & & & & 外恥道深部 & & & & \\
\hline 岩期 & 1931 & 2 & & & & & & & & 整形造孔与:菸 & & \\
\hline 去淆 & 1934 & $\begin{array}{|ll|}3 & \\
& 28, y\} \\
\end{array}$ & 人未一州故 & & 1311 & & & 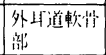 & & 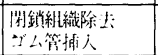 & & \\
\hline 進㤞:5 & 1942 & 4 & $\begin{array}{l}\text { 莎性: ソ-ダ液 } \\
\text { の飛泍 }\end{array}$ & & & & & $\begin{array}{l}\text { 外出道人11 } \\
\text { 战 }\end{array}$ & & & & \\
\hline 小会 ${ }^{6}$ & 1950 & $\begin{array}{ll}5 & \\
& 20 \text { 女 } \\
\end{array}$ & 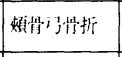 & 耳出俱( & 1 体 & & & & 具珠䏦扸成 & 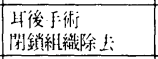 & & \\
\hline 生駒》 & 1954 & 6 & 目動車事故 & & & & & & & 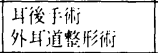 & & \\
\hline \begin{tabular}{r|}
8 \\
伊集院
\end{tabular} & 1955 & $\begin{array}{|ll|}7 & 18 \text { 年 } \\
\end{array}$ & 白動車事故 & & 1 隹: & & & 外渞外 $1 / 3$ & & 枝清移枮 & & \\
\hline 市源 ${ }^{9}$ & 1957 & $\begin{array}{|ll|}8 & \\
& 35 \\
\end{array}$ & 銃 弾 & & & & & 耳价帘形 & 真珠䐺形成 & 中国根治打街 & & \\
\hline 岩井101 & 1959 & 9 & 和ままたた䋖众 & & & & & & & 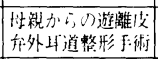 & & \\
\hline 大崎 ${ }^{11}$ & 1960 & $\begin{array}{|ll|}10 & \\
& 5\end{array}$ & 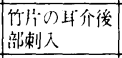 & 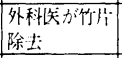 & 1511 & & & 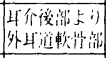 & 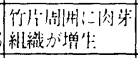 & & & \\
\hline 滝田 ${ }^{12}$ & 1962 & 11 & & & 9 sH & & & & & & & \\
\hline 関谷 ${ }^{1}$ & 1965 & \begin{tabular}{|lll}
12 & & \\
& & \\
& 11 & \\
& 93
\end{tabular} & 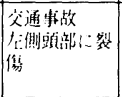 & 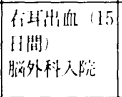 & 1811 & 難 聴 & 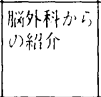 & 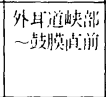 & & $\begin{array}{l}\text { 外与道形成術 } \\
\text { 鼓客形成術! 型 }\end{array}$ & $45 / 10$ & \\
\hline 松崎 ${ }^{13}$ & 1968 & $19^{\mathrm{m}}$ & 父通粠故 & 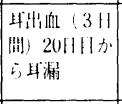 & 3011 & 難 聴 & & 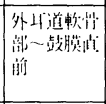 & 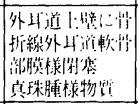 & 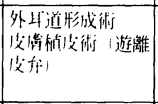 & $38 /-3$ & \\
\hline 馬場 14 & 1973 & 汝 & 父通事故 & & $10 \rightarrow H$ & $\begin{array}{l}1 \text { 出月後上 } \\
\text { i) 難聴 }\end{array}$ & \begin{tabular}{|l} 
蜼聴いた奴 \\
米院
\end{tabular} & 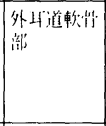 & & 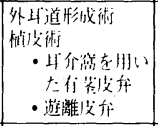 & $3.3 /$ & \\
\hline \multirow[t]{3}{*}{ 関谷 } & \multirow[t]{3}{*}{1976} & 46 男 & 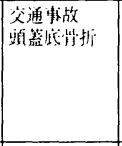 & 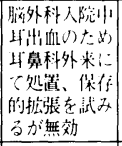 & $16 ! 1$ & \begin{tabular}{|ll} 
難 & 聴 \\
年 & 闲
\end{tabular} & 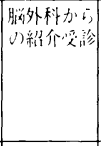 & 外出道诶部 & 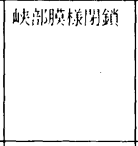 & $\begin{array}{l}\text { 結外乎道 } \\
\text { Z-plasty }\end{array}$ & $47 /$ & \\
\hline & & $\left.17^{1}\right)$ & \begin{tabular}{|l|} 
耳介後部ガラ \\
久破片刺划创
\end{tabular} & 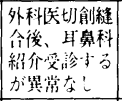 & 1 年: 9 , 1$\}$ & \begin{tabular}{|ll} 
蜼 & 聴 \\
4 & Uif
\end{tabular} & $\begin{array}{l}\text { 校㛟衫加 } \\
\text { 秎介 }\end{array}$ & 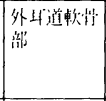 & 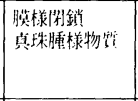 & 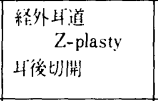 & $32 /$ & \\
\hline & & $\begin{array}{|ll|}17 & \\
& 3 \% \\
\end{array}$ & $\begin{array}{l}\text { 早介後部ガラ } \\
\text { 又破片刺切㓱 }\end{array}$ & 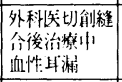 & & & $\begin{array}{l}\text { 外科から維 } \\
\text { 介 }\end{array}$ & & $\begin{array}{l}\text { 外山道にガラ } \\
\text { 蝴人 }\end{array}$ & 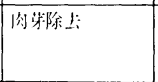 & & \\
\hline \multirow[t]{5}{*}{ 森満 } & \multirow[t]{5}{*}{1980} & 30 男 & 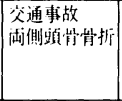 & 4保血 & 3411 & 蜼 聴 & & 外工道州激 & 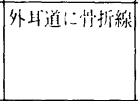 & 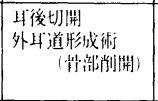 & $\begin{array}{c}\text { A-Bgap } \\
37\end{array}$ & \\
\hline & & 9男 & 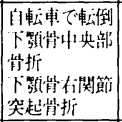 & 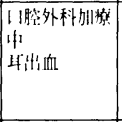 & & 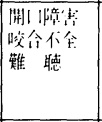 & 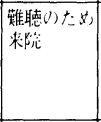 & 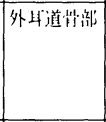 & 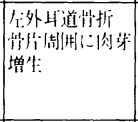 & 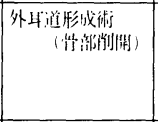 & $\begin{array}{c}\text { A-Bgap } \\
23\end{array}$ & \\
\hline & & 18男 & \begin{tabular}{|l|} 
交通事故 \\
耳介後部に裂 \\
傷
\end{tabular} & \begin{tabular}{|l|} 
外科で裂傷部 \\
の䋖合F術
\end{tabular} & 3年 & \begin{tabular}{|ll} 
耳 & 听焎 \\
難 & 聴
\end{tabular} & 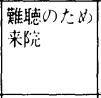 & \begin{tabular}{|l|} 
外耳道軟消 \\
能
\end{tabular} & & 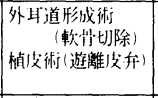 & $\begin{array}{c}\text { A-Bgap } \\
30\end{array}$ & \\
\hline & & $\begin{array}{|ll|}21 & \\
& \\
& 20 \text { 男 } \\
\end{array}$ & $\begin{array}{l}\text { 交通事故、耳 } \\
\text { 介と外耳道の } \\
\text { 弁状剝離 }\end{array}$ & \begin{tabular}{|l|} 
外科で裂傷部 \\
の栈合手術
\end{tabular} & $2+11$ & & & 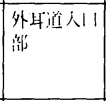 & & 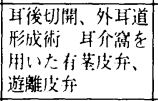 & $\begin{array}{c}\text { A-Bgap } \\
32\end{array}$ & \\
\hline & & $\begin{array}{|ll|}22 & \\
& 54 \text { 男 } \\
\end{array}$ & $\begin{array}{l}\text { 工場爆発事故 } \\
\text { で左顔面火傷 }\end{array}$ & & & 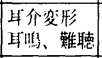 & & $\begin{array}{l}\text { 外耳“道人11 } \\
\text { 战 }\end{array}$ & 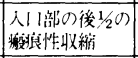 & \begin{tabular}{|l|} 
Z-plasty \\
耳尔形成術
\end{tabular} & & \\
\hline 大石 & & 56 男 & \begin{tabular}{|l|} 
単車で転倒 \\
下頻正中部骨 \\
折 \\
下頻骨両側関 \\
節突起骨折 \\
下頻骨左筋突 \\
起骨折
\end{tabular} & 両耳出血 & 2 力H & $\begin{array}{l}\text { 開1 障畫: } \\
\text { 両側難稣 }\end{array}$ & $\begin{array}{l}11 \text { 腔外科か } \\
\text { ら紹介 }\end{array}$ & \begin{tabular}{|l|} 
両側 \\
外耳道軟, 背 \\
部一骨部
\end{tabular} & $\begin{array}{l}\text { 们外耳道的下壁 } \\
\text { 比折線 } \\
\text { 真珠腫様物斦 }\end{array}$ & \begin{tabular}{|l|} 
外耳道形成術 \\
植皮这( 遊離伎升)
\end{tabular} & $\begin{array}{l}\text { ti } 51 / 6 \\
\text { 左 } 38 / 16\end{array}$ & 刚 2 参照 \\
\hline
\end{tabular}


受傷時，ほとんどの例で耳出血が認められて いるが，早期に耳鼻科を受診したものは少なく 難聴を自覚してはじめて診察をうける様であ る. 聴力像は, 中耳伝音機能に異常がなけれ ば, 30〜 60dBの伝音性難聴を示す.

4. 外耳道真珠腫症の合併

本症において, 症例番号 $5,8,13,16$, 及 び, 自験例右側外耳道の様に閉塞部より内側に 真珠腫あるいは真珠腫樣物質が認められること がある. この成因として松崎ら ${ }^{13)}$ は, 刺激説, 外傷説の 2 説をあげている.すなわち刺激説は 外耳道の遷延性の充血が局所の表皮剝離を誘発 し, それに耳垢, 脂漏などが加わり栓を形成 し，それらがさらに外耳道を刺激して表皮の剝 離を促してしだいに層状構造が形成されるとい うもので, 外傷説は, 外傷により外耳道に生じ た裂傷部位から表皮が侵入し, 内部で異所的増 殖を起こし真珠腫が形成されるという説であ る.もし，乙れらの真珠腫を放置すれば，真珠 腫は中耳に侵入し中耳伝音系を破壊し，しいて は二次感染による頭蓋内合併症をおてす可能性 もでてくる．このととより本症の臨床的重要性 を強調したい.

5 . 治療

Spector ら ${ }^{201}$ は, 肉芽増生のおこりはじめで まだ線維化が起っていない場合, 副腎皮質ホル
モン，抗生剂を塗布した適当な材質の拡張子を 留置しておけば, 肉芽増生による狭窄を予防で きると報告している，しかし発見が遅れ肉芽が 結合性に固定してしまえば, 治療は, 外科的操 作によらねばならない，本疾患に対する外耳道 再建術の原則は, 狭窄あるいは閉塞部位を切除 しその内側に病変があれば清掃し本来の外耳道 の広さにするのに加え再狭窄を予防することに ある，本症では，乙の術後再狭窄が生じ易く， このため種々の工夫がなされた手術方法が報告 されている. しかし，1つの手術法のみが全て の症例に好結果をもたらすとは限らない.それ ぞれの症例を検討した上で, 手術法を選択し実 施すればよいと思われる。

6. 予防

表 1 より受傷時, 耳出血が認められても耳処 置を受けず病期が進行し難聴を自覚するように なってから受診する例が多いといえる，又，受 傷後外耳道は異常がなくても，その後発症する 例もある（症例番号 6 )。 よって頭部外傷例で 耳出血がある場合, 受傷後早期に耳鼻科医の診 察治療を受けることが望ましく, 初診時狭窄が なくても，外耳道の皮膚の断裂ビランの見られ る場合には，経過観察することが本症発症予防 に有効であろう。

語

外傷性外耳道閉鎖症の 1 症例を報告し, 過去の報告例を通じて本症の原因と成因, 頻度, 症状, 手術および予防について考察を加えた。 今後も交通事故の激増に伴い，交通外傷による本症の増加 が予想されるが, 頭部外傷例では耳鼻科的診療を積極的に行ない本症予防に努めることが望まれる.

文

1 ) 関谷 透, 原八洲雄 : 外傷性外耳道閉鎖症症例. 耳喉 $37: 441 \sim 444,1965$.

2 ) 古井丑三郎 : 外傷性外聴道索状㵠着に就て. 日耳 鼻 $10: 69 \sim 70,1904$.

3 ) 岩田呴忽七: 外傷性外聴道索状瘾着汇就て. 耳喉 $4: 369,1931$.

4 ）吉沢英一：外傷性外耳道閉塞症の治験例. 耳喉
$7: 773 \sim 775,1934$.

5 ) 進宅外雄: 後天性外聴道閉鎖症に合併せる中耳 炎. 耳喉 15:86, 1942 .

6) 小倉弘治：外傷性外耳道閉鎖症並儿外耳道真珠症 の 1 治験例. 耳啒 $22: 417,1950$.

7 ) 生駒亮一：外傷性外耳道閉鎖症の一例. 日耳鼻 $57: 102,1954$. 
8 ) 伊集院健：外傷性外耳道閉鎖症例. 日耳鼻 58 : 78, 1955.

9 ）市原正雄：外傷性外耳道閉塞症と合併せる耳介変 形の 1 治験例. 耳喉 $29: 1026,1957$.

10）岩井一：外傷性外耳道閉鎖症例. 日耳鼻 62 : $865,1959$.

11）大崎英一：外傷性外耳道異物症例. 耳鼻臨床 $53: 1196,1960$

12）滝田孫一：外耳道閉鎖症の症例. 日耳鼻 65 ： 905, 1962.

13）松崎 力, 他：後天性外耳道閉塞症の 2 例. 耳喉 $40: 27 \sim 34,1968$.

14）馬場駿吉, 他：後天性外耳道狭窄の 2 症例とその 修復手術. 耳喉 $45: 121 \sim 126,1973$.

15）関谷 透, 他：外傷性外耳道閉鎖 -4 症例の検討 と手術法の選択. 耳喉 48 : 901 907, 1976.
16）森満 保, 他：外傷性外耳道閉鎖症の修復. 耳鼻 臨床 $26: 21 \sim 25,1980$.

17) Conley JJ : Atresia of the external auditory canal. Arch Otolaryngol $43: 613 \sim 622,1946$.

18) Miller GW: Treatment of acute canal stenosis with an expanding cellulose wick. Arch Orolaryngol $104: 55 \sim 56,1978$.

19) Akers JO, et al : Posterior dislocation of the mandibular condyle into the external ear canal. JAMA $40: 369 \sim 370,1982$.

20) Spector GJ, et al : STSG in canaloplasty. Laryngoscope $89: 674 \sim 676,1979$.

原稿到着：昭和60年 2 月 25 日 別刷請求先：大石公子 于514津市江戸橋 2 丁目174番地 三重大学医学部耳鼻咽喉科学教室 